\title{
THE EXPERIENCE OF ANTENNARIA DIOICA APPLICATION IN FOLK MEDICINE AND PROSPECTS OF THIS PLANT USE FOR CREATION OF NEW PHYTOHEMOSTATICS
}

The searching for the new effective and safe medicines is still important problem for today. Perspective subjects in this field are medicines of plant origin. It is well known that a number of diseases, labor, surgeries are often accompanied by bleedings. In such cases for their pharmacological correction hemostatic agents are used, particularly ones of plant origin, where nomenclature of drugs is comparatively not large. However, among big variety of medicinal plants there is one unjustly forgotten plant that is Antennaria dioica. This plant is non-officinal for today and according to the data in literature is applied only in folk medicine. Analysis of data in literature shows that Antennaria dioica contains complex of biologically active substances, which causes different pharmacological effects, that explains possibility of this plant application in great number of pathologies. In the available scientific literature there is no information about study and creation of Antennaria dioica medicines (except galenic ones in folk medicine) that substantiates the importance of further investigation of the properties of this medicinal plant. The prospect direction in this field is application of Antennaria dioica medicines as hemostatics for prevention and stoppage of bleedings of different ethiology.

Key words: plant origin medicines; hemostatic agents; bleedings; Antennaria dioica

\section{INTRODUCTION}

The searching for the new effective and safe medicines is still important problem for today. Perspective subjects in this field are medicines of plant origin. There is no doubt, that medicines of synthetic origin in majority of cases are highly effective for treatment of many diseases. However, almost all of them possess serious negative side effects, assist of unwanted complications development, finally leading to discontinuation of therapy by these drugs.

Medicines of plant origin have very important peculiarity: they affect living organism more physiologically than synthetic medicines. Such a "physiologicity" of medicinal plants to the sick organism leads to milder and safer therapeutic effect occurance, without harmful side effects and promotes coming of favorable long-term results.

Because of this in many cases when pathology is not severe, not complicated or chronic (sluggish and slowdurating) medicines of plant origin are the drugs of choice $[2,5,11,15,24,33]$.

Nowadays phytomedicines are used in many branches of medicine. But their amount in different pharmacological groups varies $[4,15,16,26,32,33,37,38]$.

(c) Group of authors, 2016
It is well known that a number of diseases, labor, surgeries are often accompanied by bleedings. In such cases for their pharmacological correction hemostatic agents are used, particularly ones of plant origin, where nomenclature of drugs is comparatively not large [28-30, 32, 34].

Today clinically as phytohemostatic medicines agents, obtained from following officinal medicinal plants such as Lagochilus inebrians Bge., different kinds of Polygonum, Viburnum opulus L.J., Capselia bursa pastoris L. Medik., Achillea millefolium L., Urtica dioica L., Arnica montana L., Hypericum perforatum, Sanguisorba officinalis and others, are used [25, 27, 30-33, 35].

Now it is proved, that hemostatic effect of plants develops due to presence in their phytochemical composition calcium salts, vitamin $\mathrm{K}$, tannins, ascorbic acid, rutin, several alkaloids, flavonoids, resins, organic acids.

In this connection above named medicinal plants and drugs obtained from them are indicated in hemorrhoidal, intestinal, uterine (including menstrual), nasal bleedings; treatment of bleeding gums, wounds and ulcers; hemorrhagic diathesis and so on [8-11, 28, 30].

It means, that due to the hemostatic effect these plants are useful in obstetrics and gynecology, surgery and traumatology, gastroenterology, that determines their clinical value and substantiates the prospects of further search and creation of new members in this pharmacological group. 
Table 1

\section{PHYTOCHEMICAL COMPOSITION AND PHARMACOLOGICAL PROPERTIES OF ANTENNARIA DIOICA}

\begin{tabular}{|c|c|}
\hline Group of BAS & Pharmacological properties \\
\hline Tannins & $\begin{array}{l}\text { Suppression of inflammation, located in } \\
\text { the mouth mucous membrane, intestine; } \\
\text { decrease of secretory function of gastro- } \\
\text { intestinal tract; neutralization of negative } \\
\text { effects of heavy metals. Locally: astringent } \\
\text { (low doses) effect, cauterizing (big doses) } \\
\text { effect on the mucous membranes }\end{array}$ \\
\hline Resins & $\begin{array}{l}\text { Slowdown of putrefaction in the intestine, } \\
\text { reparation and disinfection of wounds, } \\
\text { antibacterial effect, stimulation of immunity }\end{array}$ \\
\hline Saponins & $\begin{array}{l}\text { Stimulation of bronchial glands secretion, } \\
\text { stimulation of cough center, normalization of } \\
\text { water-salt metabolism, enhancing of hormonal } \\
\text { functions. Diuretic and laxative effect }\end{array}$ \\
\hline Vitam & $\begin{array}{l}\text { Increase of blood coagulation (assistance } \\
\text { in prothrombin formation), resulting in } \\
\text { stoppage of bleedings. Normalization of liver } \\
\text { functions, neutralization of harmful effects } \\
\text { of toxins, accumulating in the organism; } \\
\text { promotion of osteocalcin (protein of bone } \\
\text { tissue where calcium crystallizes) synthesis; } \\
\text { prevention of osteoporosis development, } \\
\text { regulation of reduction/oxidation processes }\end{array}$ \\
\hline Alka & $\begin{array}{l}\text { Inhibition of pain, decrease of blood } \\
\text { pressure, normalization of blood circulation, } \\
\text { increase of blood coagulation, regulation of } \\
\text { CNS functions (stimulative effect in small } \\
\text { doses and suppressive effect in high doses) }\end{array}$ \\
\hline Octacosan & $\begin{array}{l}\text { Increase of physical resistance, motor } \\
\text { reaction time reduction, antistress effect, } \\
\text { inhibition of pain in muscles after intensive } \\
\text { physical activity, in case of muscular } \\
\text { dystrophy and other neuro-muscular } \\
\text { diseases; decrease of cholesterol } \\
\text { level in blood }\end{array}$ \\
\hline Phytosterol & $\begin{array}{l}\text { Participation in processes of cholesterol } \\
\text { and steroid hormones synthesis, formation } \\
\text { of cell membranes; prevention of cardio- } \\
\text { vascular and autoimmune diseases } \\
\text { development, neutralization of viruses, } \\
\text { strengthening of immunity, detoxication, } \\
\text { improvement of mental and physical } \\
\text { activity, regulation of water-salt metabolism }\end{array}$ \\
\hline Ascorbic acid & $\begin{array}{l}\text { Decrease of concentration of uric acid in } \\
\text { blood, regulation of redox processes in } \\
\text { cell respiration, stimulation of immunity, } \\
\text { decrease of capillary permeability, } \\
\text { assistance in growth and development of } \\
\text { bone tissue, in synthesis of hormones of } \\
\text { adrenal glands; elimination of cancerogenic } \\
\text { toxins }\end{array}$ \\
\hline Volatile oils & $\begin{array}{l}\text { Normalization of cardio-vascular system } \\
\text { functions, expectorant and mucolytic } \\
\text { effects, improvement of functions of gastro- } \\
\text { intestinal tract, inhibition of inflammation }\end{array}$ \\
\hline
\end{tabular}

Besides named officinal plants, in folk medicine also non-officinal ones such as Lysimachia vulgaris, Veronica officinalis, Erigeron canadensis, Hieracium pilosella, Trifolium repens and others are used as blood-stopping agents [23-25].

However, among big variety of medicinal plants there is one unjustly forgotten plant that is Antennaria dioica. This plant is non-officinal for today and according to the data in literature is applied only in folk medicine.

Antennária dióica (L.) Gaertn., fam. Asteraceae is a perennial herb, distributed in sub-arctic, medium humid and medium continental climatic zones of Europe, Asia and North America. In Ukraine it grows everywhere.

The folk name of this plant is "cat's paw". This name occurred because Antennaria dioica has soft to the touch and velvety blossoms shaped like a cat's paw. One more folk name of Antennaria dioica is Helichrysum album [1, $6,11-14,18,19,35,36,38,39]$.

Our forefathers were sure that it is possible to treat about "hundred of diseases" using the herb named cat's paw. Sometimes Antennaria dioica was called as "pectoral herb" because it assists in treatment of respiratory diseases, especially colds.

It is known from the data in literature, that herb and flowers of Antennaria dioica contain different biologically active substances (BAS) due to which it possesses a great number of therapeutic effects (Tab. 1) [17, 20-23, 28, 30].

Analysing information presented in table 1 it is possible to conclude that due to its composition Antennaria dioica causes reparative, hemostatic (it is proved that ability of Antennaria dioica BAS to decrease of blood-clotting time and to stop hemorrhages of different origin is stronger than the same effect of adrenaline and calcium chloride), choleretic (it promotes dissolution and elimination of concrements in gallbladder), analgesic (it inhibits pain in case of gout), antitumor, anti-inflammatory, spasmolytic, vasodilating, diuretic, sedative, antitussive effects.

Taking into account a great number of pharmacological effects of Antennaria dioica, drugs obtained from it are used in folk medicine for the treatment of different diseases of organs and systems in human body (Tab. 2) $[3-5,7,9-11,17,24,26]$.

For treatment of listed above diseases (Tab. 2) on the base of Antennaria dioica different galenic medicines have been already prepared such as infusions, decoctions, dry powder of herb, lotions, cataplasms $[5,15,17,21$, $22,25,33,35]$.

According to the data in literature, infusion of Antennaria dioica is used as choleretic agent in cholecystitis, functional disorders of gallbladder and biliary tract (especially, if this disorders are accompanied by hypertensive form of dyskinesia), and also it is used in diseases of stomach (peptic ulcer, gastritis). There are data, that infusion of Antennaria dioica herb improves vision and it is used for treatment ophthalmic diseases such as glaucoma and cataract. The efficacy of infusion intake is 
marked at the early stages of these diseases and in long term administration.

As a rinsing, infusion is indicated in diseases of throat and mouth. As a cataplasm infusion is recommended in abscesses, increase of the size of thyroid gland and in hurts. Also infusion obtained from Antennaria dioica is used in gonorrhea as irrigations of the vagina.

Besides infusion, in phytotherapy a powder, prepared by shredding of dry herb, is used. It assists reparation of wounds, burns and hurts. For these purpose powder should be applied to the damaged parts of skin several times a day.

Decoction of the plant is effective for treatment of slowly reparated wounds and furuncles. Moreover decoction of Antennaria dioica as a topical preparation (lotion and washing) is indicated in dermatitis, infantile eczemas, tuberculosis of skin. And it is known, that decoction may be used also internally that improves the efficiency of therapy.

It is necessary to pay attention, that Antennaria dioica (Tab. 1) contains complex of the BAS, which have hemostatic effect (some of them are present also in wellknown traditional plants-hemostatics) that allows to suggest the presence of named activity of Antennaria dioica and is proved by data in literature $[10,15,24,29,30]$.

For example, infusion of Antennaria dioica herb and flowers is used internally for treatment of hemoptysis, plentiful menstruation, bleedings (uterine, nasal, gastro-intestinal, after labor, pulmonary, hemorrhoidal, traumatic ones). In hemorrhoidal and nasal bleedings agents from Antennaria dioica are used both internally and externally (lotions).

It is known, that combination in infusion of Antennaria dioica of anti-inflammatory and hemostatic effects substantiates application of this infusion (as rinsing) in case of inflammation of gums (accompanied by bleedings), stomatitis, parodontosis and other diseases of the mouth.

According to the information in scientific literature $[2,17,25,28-30]$ the possible mechanism of hemostatic effect of preparations of Antennaria dioica, in particular, in case of uterine bleedings, is connected to the stimulation of uterine contractions by alkaloids, volatile oils and other BAS. As a result this effect leads to stoppage of hemorrhages due to vasoconstriction. Several authors also point out direct vasoconstrictive effect of Antennaria dioica BAS to the small arteries, arterioles and capillaries resulting in decrease of bleedings as well. Vitamin K, in its turn, participates in formation of prothrombin in liver, increasing blood coagulation. In addition, it is necessary to take into account the role of such BAS as ascorbic acid and tannins in hemostatic effect development.

\section{CONCLUSIONS}

Thus, analysis of data in literature shows that Antennaria dioica contains complex of BAS, which causes different pharmacological effects, that explains possibility of this plant application in great number of pathologies.
Table 2

\section{APPLICATION OF ANTENNARIA DIOICA IN FOLK MEDICINE}

\begin{tabular}{|l|l|}
\hline Organ / System of organs & \multicolumn{1}{|c|}{ Diseases } \\
\hline Central nervous system & $\begin{array}{l}\text { Disorders of neuro-muscular } \\
\text { conductivity, dystrophy of } \\
\text { muscles, stress }\end{array}$ \\
\hline Respiratory system & $\begin{array}{l}\text { Angina, pertussis, tuberculosis } \\
\text { of lungs, cough, bronchitis }\end{array}$ \\
\hline Cardio-vascular system & $\begin{array}{l}\text { Hypertension, bleedings, } \\
\text { hemorrhoids }\end{array}$ \\
\hline Digestive system & $\begin{array}{l}\text { Diarrhea (bloody), cholecystitis, } \\
\text { hepatitis, cholelithiasis, hepatic } \\
\text { colics, peptic ulcer, gastritis, } \\
\text { dysentery }\end{array}$ \\
\hline Reproductive system & $\begin{array}{l}\text { Disorders of menstrual cycle, } \\
\text { uterine bleedings, colpitis, } \\
\text { vaginitis, deformation of uterus, } \\
\text { gonorrhea }\end{array}$ \\
\hline Skin and mucous \\
membranes & $\begin{array}{l}\text { Infantile eczema, wounds, } \\
\text { boils, tuberculosis of skin, } \\
\text { parodontosis, furuncles, } \\
\text { dermatitis, hurts }\end{array}$ \\
\hline Others & $\begin{array}{l}\text { Glaucoma, cataract, gout, } \\
\text { tumors, abscesses, allergy, colds }\end{array}$ \\
\hline
\end{tabular}

In the available scientific literature there is no information about study and creation of Antennaria dioica medicines (except galenic ones in folk medicine) that substantiates the importance of further investigation of the properties of this medicinal plant.

The prospect direction in this field is application of Antennaria dioica medicines as hemostatics for prevention and stoppage of bleedings of different ethiology.

\section{REFERENCES}

1. Андриенко Т. Л., Перегрим М. Г. Официальные перечни регионально редких растений административных территорий Украины (справочное издание). - К.: Альтерпрес, 2012. - 300 с.

2. Асенов И. Николов С. Фармакогнозия. - София, 1988. - 300 c.

3. Ахмедов Р. Б. В растениях - целебная сила / Р. Б. Ахмедов // Из копилки народных врачевателей. 1992. - Вып. 2. - 96 с.

4. Ахметова Б. Х. Полезные лекарственные растения. - Уфа: Медгиз, 1962. - 79 с.

5. Белов В. И. Жизнь без лекарств. - С.Пб., 1994. $494 \mathrm{c.}$

6. Биологический энциклопедический словарь / гл. ред. М. С. Гиляров; Редкол.: А. А. Баев, Г. Г. Винберг, Г. А. Заварзин и др. - М.: Сов. энциклопедия, 1986. - С. 289.

7. Блехер Л. Б., Колосова Т. И. Лечебное применение лекарственных растений и приготовление препаратов в домашних условиях. - С.Пб., 1992. $228 \mathrm{c}$. 
8. Блинова К. Ф. Исследования дубильных растений. Матер. исследований лекарственных средств и сырья. - Л., 1959. - С. 60-72.

9. Бодруг М. В. Дикорастущие эфирномасличные растения Молдавии. - Кишинев: Штиинца, 1981. $141 \mathrm{c.}$

10. Варданян С. А. Фитотерапия в средневековой армянской гериатрии / С. А. Варданян // Биол. журн. Армении. - 1980. - Т. 33, № 1. - С. 108-117.

11. Вульф Е. В., Малеева О. Ф. Мировые ресурсы полезных растений. - Л., 1969. - 566 с.

12. Гейдеман Т. С. Анализ флоры сосудистых растений. Природа заповедника «Кодры». - Кишинев: Штиинца, 1984. - С. 27-34.

13. Гейдеман Т. С. О флоре сосудистых растений известняковых гряд (толтр) Молдавии. Флористические и геоботанические исследования в Молдавии. - Кишинев: Штиинца, 1980. - С. 28-36.

14. Гейдеман Т. С., Иванова Б. И., Ляликов С. И. и др. Полезные дикорастущие растения Молдавии. Кишинев, 1962. - 416 с.

15. Гесь Д. К., Горбач Н. В. Лекарственные растения и их применение. - Мн, 1976. - 200 с.

16. Гриневич М. А. Информационный поиск перспективных лекарственных растений: Опыт изучения традиционной медицины Восточной Азии с помощью ЭВМ. - Л., 1990. - 140 с.

17. Гринкевич Н. И. Справочное пособие «Лекарственные растения». - М.: Высш. шк., 1991. - 180 с.

18. Грисюк Н. М. Гринчак И. Л., Елин Е. Я. Дикорастущие пищевые, технические и медоносные растения Украины. - К., 1989. - 200 с.

19. Губанов И. А. 1261. Antennaria dioica (L.) Gaertn. Кошачья лапка двудомная // Иллюстрированный определитель растений Средней России. В 3-х т. - М.: Т-во науч. изд. КМК, Ин-т технолог. иссл., 2004. - Т. 3. Покрытосеменные (двудольные: раздельнолепестные). - С. 325.

20. Губанов И. А., Крылова И. Л., Тихонова В. Л. Дикорастущие полезные растения СССР. - М.: Мысль, 1976. - 360 c.

21. Ефремова Н. А. Заветные травы. - ПетропавловскКамчатский, 1992. - 240 с.

22. Завражнов В. И., Китаева Р. И., Хмелев К. Ф. Лекарственные растения: Лечебное и профилактическое использование. - 4-е изд. - Воронеж, 1993. - 480 c.
23. Задорожный А. М. Кошкин А. Г., Соколов С. Я., Шретер А. И. Справочник по лекарственным растениям. - 1988. - 415 с.

24. Землинский С. Е. Лекарственные растения СССР. М.: Медгиз, 1958. - 603 с.

25. Зимин В. М. Библиотечка лекарственных растений / Собрание народной и научной медицины. С.Пб., 1992. - Т. 1. - 266 с; Т. 2. - 300 с.

26. Кит С. М., Турчин И. С. Лекарственные растения в эндокринологии. - К., 1986. - 80 с.

27. Красная книга Приднестровской Молдавской Республики. - Тирасполь, 2009. - 374 с.

28. рылов А. А., Марченко В. А., Максютина Н. П., Мамчур Ф. И. Фитотерапия в комплексном лечении заболеваний внутренних органов. - К., 1991. 240c.

29. Куркин В. А. Фармакогнозия. - Самара, 2004. $200 \mathrm{c}$.

30. Лекарственные растения в научной и народной медицине. 3 изд. - Изд-во Саратовского университета, 1972. - 250 c.

31. Лікарські рослини: Енциклопедичний довідник / відп. ред. А. М. Гродзінський. - К.: Голов. ред. УРЕ, 1991. - 544 c.

32. Маевский П. Ф. Флора средней полосы европейской части России. - М.: Т-во науч. изд. КМК, 2006. - 200 c.

33. Носаль М. А., Носаль И. М. Лекарственные растения в народной медицине. - М.: СП «Внешиберика», 1991. - 200 с.

34. Нуралиев Ю. Лекарственные растения.-Н-Новгород, 1991. - 200 c.

35. Сафонов Н. «Лекарственные растения. Иллюстрированный атлас». - М.: Эксмо, 2013. - 100 с.

36. Сова Т. В. Биоразнообразие Луганского природного заповедника: растительный мир (Біорізноманітність Луганського природного заповідника: рослинний світ). - Луганск: Элтон-2, 2010. - 150 с.

37. Соколов С. Я., Замотаев И. П. Справочник по лекарственным растениям. - М., 1984. - 180 с.

38. Фруентов Н. К. Лекарственные растения Дальнего Востока. - Хабаровское книжное изд-во, 1987. - 88 c.

39. Bayer R. J. Antennaria // Flora of North America Editorial Committee. - New York: Oxford University Press, 2006. Vol. 19. Magnoliophyta: Asteridae, Part 6: Asteraceae, Part 1 (Mutisieae-Anthemideae). - P. 388. 


\section{UDC 615.451.16:615.273.5}

Д. В. Семенив, Г. В. Белик, Т. А. Куценко, Ю. В. Столетов, В. А. Уланова ОПЫТ ПРИМЕНЕНИЯ АНТЕННАРИИ ДВУДОМНОЙ В НАРОДНОЙ МЕДИЦИНЕ И ПЕРСПЕКТИВЫ СОЗДАНИЯ НА ЕЕ ОСНОВЕ НОВЫХ ФИТОГЕМОСТАТИКОВ

Поиск новых эффективных и безопасных лекарственных препаратов и сегодня является актуальной проблемой. Перспективными объектами в этом плане являются лекарственные препараты, созданные на основе лекарственных растений. Общеизвестно, что целый ряд заболеваний, а также роды, оперативные вмешательства нередко сопровождаются кровотечениями. В таких случаях для их фармакологической коррекции используют гемостатические средства, в частности растительного происхождения, номенклатура которых сравнительно невелика. Однако, среди большого разнообразия лекарственных растений есть одно незаслуженно забытое - кошачьи лапки или антеннария двудомная, которое на сегодня не является официнальным и по данным литературы пока находит применение только в народной медицине. Анализ данных литературы показал, что растение содержит комплекс биологически активных веществ, который проявляет разнообразные фармакологические эффекты, что, в свою очередь, обусловливает возможность применения этого растения при большом количестве заболеваний. В доступной нам литературе не найдено данных об изучении и создании препаратов на основе антеннарии двудомной, что обосновывает актуальность дальнейшего исследования свойств данного растения. Перспективным направлением в изучении антеннарии двудомной является ее использование в качестве гемостатика для профилактики и остановки кровотечений различной этиологии.

Ключевые слова: препараты растительного происхождения; гемостатики; кровотечения; антеннария двудомная

\section{UDC 615.451.16:615.273.5 \\ Д. В. Семенів, Г. В. Бєлік, Т. О. Куценко, Ю. В. Столєтов, В. А. Уланова \\ ДОСВІД ЗАСТОСУВАННЯ АНТЕНАРІЇ ДВОДОМНОЇ У НАРОДНІЙ МЕДИЦИНІ ТА ПЕРСПЕКТИВИ СТВОРЕННЯ НА ІІЇ ОСНОВІ НОВИХ ФІТОГЕМОСТАТИКІВ}

Пошук нових ефективних та безпечних лікарських засобів досі залишається актуальною проблемою. Перспективними об'єктами в цьому плані є ліки, створені на основі лікарських рослин. Відомо, що ціла низка захворювань, а також пологи, оперативні втручання досить часто супроводжуються кровотечами. В таких випадках для фармакологічної корекції використовують гемостатичні засоби, зокрема, рослинного походження, номенклатура яких порівняно невелика. Однак серед великого різномаїття лікарських рослин $є$ одна незаслужено забута Антенарія дводомна, яка на сьогодні $\epsilon$ неофіцинальною та поки що знаходить застосування лише у народній медицині. Проведений аналіз даних літератури показав, що антенарія дводомна містить комплекс біологічно активних речовин, які чинять чимало фармакологічних ефектів, що зумовлює можливість застосування цієї рослини при багатьох захворюваннях. У досяжній нам науковій літературі не знайдено інформації щодо вивчення та створення лікарських препаратів на основі антенарії дводомної (за винятком галунових у народній медицині), що обгрунтовує доцільність подальшого вивчення властивостей цієї лікарської рослини. Перспективним напрямком у цьому плані $є$ можливість застосування препаратів антенарії дводомної як гемостатичних засобів для профілактики та лікування кровотеч різної етіології. Ключові слова: ліки рослинного походження; гемостатики; кровотечі; антенарія дводомна

Адреса для листування:

Надійшла до редакції 28.11.2016 p.

61002, м. Харків, вул. Пушкінська, 53.

Національний фармацевтичний університет 